\section{Increasing the Yield of Soluble Recombinant Protein Expressed in E. coli by Induction during Late Log Phase}

BioTechniques 34:524-530 (March 2003)

\begin{abstract}
Recombinant mammalian proteins expressed in E. coli can be difficult to purify in high yield in a soluble and functional form. Various techniques have been described to prevent proteolysis of expressed proteins and/or their sequestering as insoluble aggregates within inclusion bodies. We report conditions for expressing recombinant proteins from E. coli that significantly enhanced the yield of soluble and functional protein. We demonstrate high-yield recovery of a native, high-molecular-weight RNA binding protein without the aid of fusion protein sequence. The principle factor that increased protein yield was the induction of protein expression in a late log phase culture, although reduced temperature during the induction and a low IPTG concentration also contributed to a higher yield.
\end{abstract}

\section{INTRODUCTION}

The preparation of recombinant mammalian proteins under native conditions is essential for functional applications including enzyme assays, the analysis of macromolecular interactions, and structural analyses. Depending on the particular protein, recombinant protein may be subjected to proteolysis within E. coli and/or sequestered as insoluble aggregates within inclusion bodies (1). Isolation of recombinant proteins from inclusion bodies is possible but typically requires denaturing conditions (2). Systems commercially available such as the yeast Pichia pastoris system (Invitrogen, Carlsbad, CA, USA), the Drosophila $\mathrm{S} 2$ cell system (Invitrogen), and the rabbit reticulocyte lysate system (Promega, Madison, WI, USA) may enable intact protein to be expressed, but frequently the yield of recombinant protein is too low for structural studies. In combination with these alternative expression systems, the protein of interest may be obtained in higher yields when it is expressed as a fusion protein to one of several commercially available conjugates [e.g., GST (Amersham Biosciences, Piscataway, NJ, USA) or NusA (Novagen, Madison, WI, USA)]. Depending on the application, the protein of interest may have to be proteolytically cleaved from the fusion protein, necessitating the use of expensive proteolytic enzymes, additional purification procedures and time.

Recently, a variety of adaptations for E. coli expression of proteins have been developed that allow for a high level of protein expression and the reduction of the amount of protein lost to inclusion bodies. These include the use of E. coli host strains that overexpress heterologous tRNAs that better support mammalian preferred codon usage (Novagen and Stratagene, La Jolla, CA, USA) and modifications aimed at reducing the level of protein expression, such as lowering the concentration of IPTG used for induction (3), reducing the duration of induction (4), and lowering temperatures at which induction is performed (5). Interestingly, all of these procedures have in common the use of log phase cultures of $E$. coli, and when higher cell densities have been suggested, it is simply intended to compensate by cell number for a lower level of protein expression $(1,4)$. In this regard, we have evaluated the effect of culture density on the expression of a recombinant RNA binding protein, ACF64 (6). The data suggested that induction of recombinant protein expression in late log phase $E$. coli contributes significantly to not only the total amount of protein expressed but also enhancement of the yield of soluble protein.

\section{MATERIALS AND METHODS}

\section{The ACF64 Expression Vector}

acf64 cDNA (GenBank ${ }^{\circledR}$ accession no. AF290984) (6) comprising amino acids $1-586$ was amplified by PCR to include EcoRV and XhoI restriction sites at the $5^{\prime}$ and $3^{\prime}$ ends respectively.
The product was subcloned into a modified $p E T 28$ a (Novagen) vector at the filled NcoI and XhoI sites such that ACF64 protein was expressed with a Cterminal HA epitope and hexa-histidine motif. The sequence verified construct was transformed into E. coli BL21 (DE3) RIL Codon Plus (Stratagene).

\section{Growth Conditions}

An overnight 2-mL culture from a single colony was grown at $37^{\circ} \mathrm{C}$ in $\mathrm{LB}$ (1\% Bacto-tryptone, $0.5 \%$ Bacto yeast extract, and $0.5 \% \mathrm{NaCl}$ ) and then transferred to $50 \mathrm{~mL} \mathrm{LB}$ medium in a 250 $\mathrm{mL}$ flask and incubated at $37^{\circ} \mathrm{C}$ with shaking at $250 \mathrm{rpm}$. After $4 \mathrm{~h}$, the culture was transferred to $750 \mathrm{~mL} \mathrm{LB}$ medium in a 4-L flask and incubated as before. All cultures contained $20 \mu \mathrm{g} /$ mL kanamycin.

\section{Induction of Protein Expression}

Growth of cultures was monitored by their $\mathrm{A}_{600}$. Protein expression was induced in $\log$ phase at $\mathrm{A}_{600}=0.6$ or in late log phase at $\mathrm{A}_{600}=1.7$ at either $30^{\circ} \mathrm{C}$ or $37^{\circ} \mathrm{C}$ with IPTG at concentrations of 0.1 or $1 \mathrm{mM}$. For $30^{\circ} \mathrm{C}$ inductions, cultures were placed in ice water (without shaking for $5 \mathrm{~min}$ ) to rapidly lower the temperature, IPTG was added, and the cultures were placed at $30^{\circ} \mathrm{C}$ and shaken at $250 \mathrm{rpm}$. Control experiments demonstrated that a slower rate of cooling down (e.g., leaving the culture at room temperature for 15 min) worked as well. For $37^{\circ} \mathrm{C}$ inductions, IPTG was simply added to cultures at $37^{\circ} \mathrm{C}$ and shaking continued. All inductions were stopped, after $1 \mathrm{~h}$, by placing flasks on ice.

\section{Preparation of Protein Extracts}

After induction, cells were collected $\left(10000 \times g\right.$ for $10 \mathrm{~min}$ at $\left.4^{\circ} \mathrm{C}-7^{\circ} \mathrm{C}\right)$, and the cell pellet was resuspended in the equivalent of eight cell pellet volumes with lysis buffer consisting of $0.1 \times$ PBS (15 mM NaCl, $0.6 \mathrm{mM} \mathrm{K}_{2} \mathrm{HPO}_{4}$, $\left.0.2 \mathrm{mM} \mathrm{KH}_{2} \mathrm{PO}_{4}, \mathrm{pH} 7.3\right), 3 \mathrm{mM} \beta$ mercaptoethanol, $0.1 \mathrm{mM}$ PMSF, 0.5 $\mu \mathrm{g} / \mathrm{mL}$ aprotinin (Sigma, St. Louis, MO, USA), leupeptin , pepstatin (Sig$\mathrm{ma}), 0.6 \mathrm{mM}$ benzamidine, and 1 $\mathrm{mg} / \mathrm{mL}$ lysozyme (Sigma) and incubat- 


\section{Short Technical Reports}

ed for $15 \mathrm{~min}$ at $37^{\circ} \mathrm{C}$. The lysate was shell-frozen in liquid nitrogen (by rapidly swirling it along the side of the centrifuge bottle while submerged in liquid nitrogen) followed by thawing completely at $37^{\circ} \mathrm{C}$. This was repeated three times. At this point, the initial lysate viscosity was diminished. The lysate was adjusted to $5 \mathrm{mM} \mathrm{MgSO}$ and $2 \mathrm{mM}$ ATP and digested with $10 \mu \mathrm{g}$ DNase I (Sigma) and $50 \mu \mathrm{g}$ RNase A (Sigma) $/ \mathrm{mL}$ at $37^{\circ} \mathrm{C}$ for $20 \mathrm{~min}$. The lysate was adjusted to $1 \mathrm{M} \mathrm{NaCl}$ and $0.4 \%$ Triton $\mathrm{X}-100^{\circledR}$ and incubated on ice for $5 \mathrm{~min}$ before preparing a cleared lysate supernatant by centrifugation at $16000 \times g$ for $10 \mathrm{~min}$ at $4^{\circ} \mathrm{C}-7^{\circ} \mathrm{C}$. For comparative analysis to the supernatant, the resultant pellet was resuspended to the same volume as the extract supernatant using lysis buffer containing $1 \mathrm{M} \mathrm{NaCl}$ and $0.4 \%$ Triton $\mathrm{X}-100$. The distribution of ACF64 as soluble (supernatant) and insoluble (resuspended pellet) was evaluated by resolving an equal aliquot of each fraction by $10.5 \%$ SDS-PAGE and Coomassie Blue ${ }^{\circledR}$ staining.

\section{Nickel Affinity Purification}

The supernatant (typically $40 \mathrm{~mL}$ ) was bound to Ni-NTA resin (Qiagen, Valencia, CA, USA) (2 mL packed resin) in the presence of $10 \mathrm{mM}$ imidazole at $4^{\circ} \mathrm{C}$ for $2 \mathrm{~h}$ while tumbling. The resin was then poured into a $15-\mathrm{mL}$ disposable column (Bio-Rad Laboratories, Hercules, CA, USA), and the flow through lysate (unbound fraction) was collected. The resin was washed consecutively with $50 \mathrm{~mL}$ wash buffer 1 (lysis buffer containing $1 \mathrm{M} \mathrm{NaCl}$ but lacking reducing agent and protease inhibitors) and $50 \mathrm{~mL}$ wash buffer 2 (wash buffer 1 containing $150 \mathrm{mM} \mathrm{NaCl}$ ) and then eluted in wash buffer 2 containing $300 \mathrm{mM}$ imidazole as $0.7-\mathrm{mL}$ fractions. Aliquots of the eluted fractions $(8 \mu \mathrm{L})$ were analyzed by SDS-PAGE. The total yield of
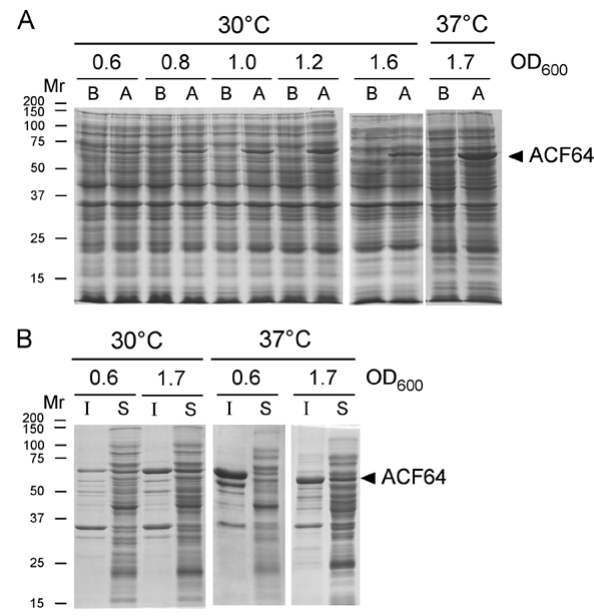

Figure 1. Enhanced expression of soluble recombinant ACF. (A) The induction of protein expression. E. coli strain BL21 (DE3) RIL Codon Plus transformed with pET28a-ACF64 were grown at $37^{\circ} \mathrm{C}$ to the indicated $\mathrm{A}_{600}$, and heterologous protein expression was induced with $0.1 \mathrm{mM}$ IPTG for $1 \mathrm{~h}$ at either $30^{\circ} \mathrm{C}$ or $37^{\circ} \mathrm{C}$ as described in the Materials and Methods section. Protein expression from an equal aliquot of cells before ("B") and after ("A") induction were resolved by $10.5 \%$ SDS-PAGE. (B) The distribution of expressed protein as soluble and insoluble fractions. Cultures grown to the indicated $\mathrm{A}_{600}$ and induced with 0.1 $\mathrm{mM}$ IPTG at the indicated temperatures were lysed and extracted to obtain soluble ("S") and insoluble ("I") fractions as described in the Materials and Methods section. The insoluble material was resuspended to the original extract volume, and an equal aliquot of insoluble and soluble protein was resolved by SDS-PAGE. The migration of molecular weight standard proteins and of ACF64 are indicated as Mr and ACF64, respectively. soluble ACF64 was estimated by comparing the density of a fraction of the total purified ACF64 against a known mass of BSA from Coomassie Blue-stained gels.

lated from the concentration of ACF64 in each fraction and the molecular weight of ACF64. The reactions were exposed to $254 \mathrm{~nm}$ UV light in $0.5 \mathrm{~cm}$ width quartz cuvettes on ice for $5 \mathrm{~min}$ and subsequently digested with $20 \mathrm{U}$ each RNase A and RNase T1 (Sigma) for $30 \mathrm{~min}$ at $37^{\circ} \mathrm{C}$. Protein was precipitated with 5 volumes of acetone, and the dried pellets were resuspended in SDSPAGE sample treatment buffer and resolved on $10.5 \%$ SDS-PAGE, and the radiolabeled proteins were visualized by autoradiography.

\section{RESULTS}

RNA binding proteins play important roles in cellular structure and function; consequently, it is of interest to isolate and characterize these proteins $(9,11)$. The $64-\mathrm{kDa}$ ACF64 is an essential component of the complex known as the $\mathrm{C} \rightarrow \mathrm{U}$ editosome involved in carrying out hydrolytic deamination of cytidine to form uridine at nucleotide position 6666 in apolipoprotein B mRNA $(6,12,13)$. ACF64 contains three RNA recognition motifs involved in site-specific binding to apoB mRNA and interacts with the editing deaminase, APOBEC-1.

To isolate ACF64 for functional stud-

Assembly of RNA-Protein Complexes and UV LightInduced Cross-Linking

RNA-protein interactions were evaluated by UV light cross-linking as described previously $(7,8)$. Briefly, 40 fmol of a $\alpha-\left[{ }^{32} \mathrm{P}\right]$ ATP uniformly labeled 498-nucleotide apoB RNA [transcribed and $5^{\prime}$-capped with T7 RNA polymerase using mMessage Machine (Ambion, Austin, TX, USA)] were incubated with varying amounts of $\mathrm{Ni}^{2+}$ affinity-purified APOBEC-1 Complementation Factor (ACF64) under editosome assembly conditions $(100-\mu \mathrm{L}$ reactions containing $10 \mathrm{mM}$ HEPES, $\mathrm{pH} 7.9,50 \mathrm{mM} \mathrm{KCl}, 30 \mathrm{mM}$ EDTA, $0.25 \mathrm{mM}$ DTT, at $30^{\circ} \mathrm{C}$ for $1 \mathrm{~h}$ ). The number of picomoles of ACF64 added to each reaction was calcuies, recombinant protein containing a $6 \times$ His tag was expressed and affinity purified by $\mathrm{Ni}^{2+}$ affinity chromatography as described in the Materials and Methods section. Soluble recombinant ACF64 was recovered in low yields (50-100 $\mu \mathrm{g} / 3 \mathrm{~L}$ culture) when expressed under standard conditions in E. coli. Yields in an E. coli-based coupled in vitro transcription-translation system (Roche Applied Science, Indianapolis, IN, USA) were 100 to 500 times lower, making this approach for scale-up cost prohibitive. Modifications of the conditions for $E$. coli expression were evaluated including lower IPTG concentration for induction, reduced temperature, and shorter periods of induction. All three conditions together enhanced the yields of soluble ACF64 (see below), but the most significant factor that contributed to increased soluble ACF was induction of protein expression at late log phase.

IPTG induction at a culture density of $\mathrm{A}_{600}=0.6$ is a typical recommendation of most protocols. An evaluation 


\section{Short Technical Reports}

of the amount of ACF64 that could be induced at various culture densities revealed protein expression levels increased with increasing culture density regardless of whether induction was carried out at $30^{\circ} \mathrm{C}$ or $37^{\circ} \mathrm{C}$ (Figure 1A). Following lysis and extraction of cells as soluble and insoluble fractions as described in the Materials and Methods section, the yield of soluble ACF64 in cells grown to mid log phase and induced at $30^{\circ} \mathrm{C}$ was found to be higher than that obtained from cells grown to mid $\log$ phase and induced at $37^{\circ} \mathrm{C}$ (Figure 1B). The highest yield of soluble ACF64 was obtained from cells grown to late log phase at $37^{\circ} \mathrm{C}$ regardless of whether induction was carried out at $30^{\circ} \mathrm{C}$ or $37^{\circ} \mathrm{C}$. In other experiments (not shown), the recovery of soluble ACF64 was not enhanced further by growth to late log phase at temperatures below $30^{\circ} \mathrm{C}$ before induction.

To evaluate the functional integrity of soluble ACF64 obtained from cultures induced during late log phase, extracts were affinity-purified and ACF64 was eluted with imidazole as described in the Materials and Methods section. The elution profile demonstrated that the highest yield of ACF64 was in fractions 3 and 4 (Figure 2). This yield was calculated to be equivalent to $4-6 \mathrm{mg}$ total soluble ACF64 from $3 \mathrm{~L}(4 \times 750$ $\mathrm{mL}$ ) culture.

UV light-induced cross-linking of radiolabeled RNA to ACF64 has been used to identify and characterize this protein as an apoB mRNA binding protein in crude liver extracts and as re-

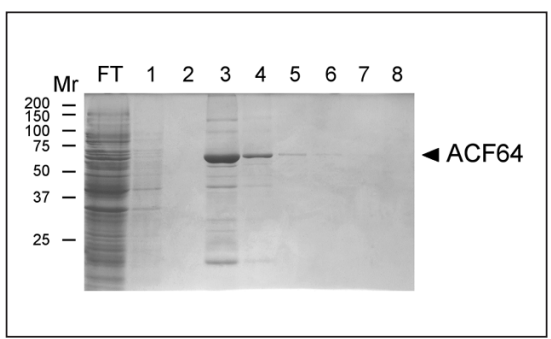

Figure 2. Purification of ACF64 by metal affinity chromatography. Soluble protein isolated from late log phase cells that were induced with $0.1 \mathrm{mM}$ IPTG at $30^{\circ} \mathrm{C}$ as described in Figure 1 were adsorbed to $\mathrm{Ni}^{2+}$ affinity resin. Unbound protein in the flow through ("FT") was collected, and bound protein was eluted with $300 \mathrm{mM}$ imidazole (fractions 1-8). The migration of molecular weight standard proteins and of ACF64 are indicated as $\mathrm{Mr}$ and ACF64, respectively. combinant protein $(7,12)$. Using this assay, the ability of ACF64 to interact with apoB RNA was shown to be proportional to the amount of protein input over the 10-fold difference in concentration tested (Figure 3).

\section{DISCUSSION}

The expression of soluble and functional recombinant protein in sufficient quantities for analytical studies is frequently limited by low yields because of cellular toxicity and/or sequestering of recombinant protein as insoluble inclusion bodies. Various methods for expressing protein in different organism or cellular backgrounds, or through in vitro translation, have been described that enable the production of soluble functional proteins $(3-5,12)$. In this regard, the data reported here demonstrated that the expression of soluble ACF64 was markedly enhanced by reducing the temperature of induction from $37^{\circ} \mathrm{C}$ to $30^{\circ} \mathrm{C}$. Consistent with literature reports, we observed that induction with 0.1 mM IPTG for $1 \mathrm{~h}$ maximized the yield of soluble recombinant protein at both $30^{\circ} \mathrm{C}$ and $37^{\circ} \mathrm{C}$. Higher IPTG concentrations and/or longer times of induction were observed to decrease the recovery of soluble ACF64 (data not shown).

Perhaps the most unexpected finding

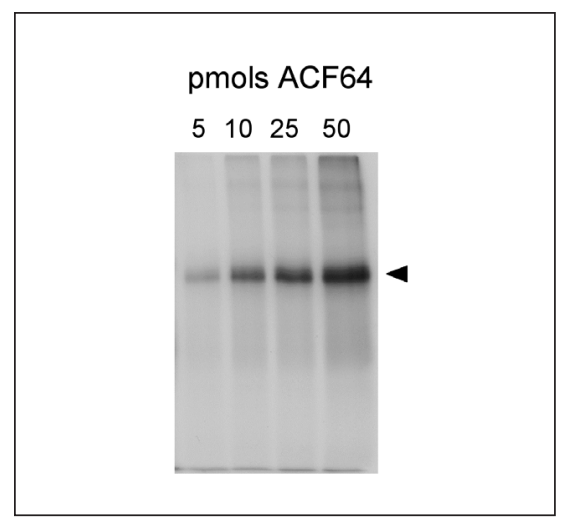

Figure 3. Analysis of RNA binding activity of purified ACF64. The indicated picomoles of $\mathrm{Ni}^{2+}$ affinity-purified recombinant ACF64 (from fraction 3, Figure 2) were incubated with $40 \mathrm{fmol}$ radiolabeled apoB mRNA under editosome assembly conditions and subjected to UV light-induced cross-linking as described in the Materials and Methods section. Reactions were resolved by SDS-PAGE and autoradiographed. The migration of the ACF64-RNA cross-linked complexes is indicated with an arrowhead. was the observation that expression of ACF64 in late log phase cultures yielded higher recovery of soluble recombinant protein than that obtained from mid log phase cultures. Most protocols for expressing recombinant protein recommend inducing protein expression when the $E$. coli culture is in mid log phase [i.e., $\left.\mathrm{A}_{600}=0.6(3-5)\right]$. This is presumably because the cultures are growing rapidly and protein translation is maximal. Expression in late log phase cultures is generally not discussed. Late log phase culture induction has been described as a means for boosting the yield of protein when the expression level was low (i.e., more cells so more protein) $(1,4)$. Importantly, the data presented here demonstrated that the increased yield of soluble ACF64 from late log phase culture induction was not merely due to the greater number of cells. Late log phase cells sequestered relatively less of the total expressed protein in inclusion bodies. This is most evident in the comparison of the relative recovery of ACF64 as insoluble and soluble material from cultures induced at $37^{\circ} \mathrm{C}$ at $\mathrm{A}_{600}=0.6$ or 1.7 (Figure 1B). We do not know why late log phase cultures are more permissive for expressing soluble proteins. The late log phase cells have undergone a metabolic and growth shift that may attenuate the response to foreign and potentially toxic proteins. Alternatively, reduced growth rates may be associated with a reduced rate of protein synthesis; hence, less aggregation within inclusion bodies occurred.

The data demonstrated the recovery of milligram quantities of soluble ACF64 from 3 L culture that was active in RNA binding, as indicated by the UV cross-linking assay. Although the utility of this protocol for different proteins should be evaluated on a case-bycase basis, we have had success with other RNA binding proteins and enzymes. Therefore, the protocol may be generally applicable and lends itself easily to the adaptation of existing $E$. coli protein expression protocols.

\section{REFERENCES}

1.Sambrook, J. and D.W. Russell. 2001. Expression of cloned genes in Escherichia coli, p. 15.1-15.19. In J. Argentine (Ed.), Molecular Cloning: A Laboratory Manual. CSH Labora- 


\section{Short Technical Reports}

tory Press. Cold Spring Harbor, NY

2.Sambrook, J. and D.W. Russell. 2001. Purification of expressed proteins from inclusion bodies, p. 15.49-15.54. In J. Argentine (Ed.), Molecular Cloning: A Laboratory Manual. CSH Laboratory Press, Cold Spring Harbor, NY

3.Winograd, E., M.A. Pulido, and M. Wasserman. 1993. Production of DNA-recombinant polypeptides by Tac-inducible vectors using micromolar concentrations of IPTG. BioTechniques 14:886-887.

4.Ausubel, F.M., R. Brent, R.F. Kingston, D.D. Moore, J.G. Seldman, J.A. Smith, and K. Struhl. 1994. Introduction to expression by fusion protein vectors, p. 16.4.2. In K. Janssen (Ed.), Current Protocols in Molecular Biology, Vol. 2. John Wiley \& Sons, New York.

5.Schein, C.H. and M.H.M. Noteborn. 1988. Formation of Soluble Recombinant Proteins in Escherichia coli is favored by lower growth temperatures. Biotechnology 6:291-294.

6.Dance, G.S.C., M.P. Sowden, L. Cartegni, E. Cooper, A.R. Krainer, and H.C. Smith. 2002. Two proteins essential for apolipoprotein B mRNA editing are expressed from a single gene through alternative splicing. $\mathrm{J}$. Biol. Chem. 277:12703-12709.

7.Harris, S.G., I. Sabio, E. Mayer, M.F. Steinberg, J.W. Backus, J.D. Sparks, C.E. Sparks, and H.C. Smith. 1993. Extract-specific heterogeneity in high-order complexes containing apolipoprotein B mRNA editing activity and RNA-binding proteins. J. Biol. Chem. 268:7382-7392

8.Smith, H.C. 1998. Analysis of protein complexes assembled on apolipoprotein B mRNA for mooring sequence-dependent RNA editing. Methods 15:27-39.

9.Dreyfuss, G., V.N. Kim, and N. Kataoka. 2002. Messenger-RNA-binding proteins and the messages they carry. Nat. Rev. Mol. Cell. Biol. 3:195-205.

10.Ganesan, S., D.P. Silver, R.A. Greenberg, D. Avni, R. Drapkin, A. Miron, S.C. Mok, V. Randrianarison, et al. 2002. BRCA1 supports XIST RNA concentration on the inactive X chromosome. Cell 111:393-405.

11.Mochizuki, K., N.A. Fine, T. Fujisawa, and M.A. Gorovsky. 2002. Analysis of a piwi-related gene implicates small RNAs in genome rearrangement in tetrahymena. Cell 110:689699.

12.Mehta, A., M.T. Kinter, N.E. Sherman, and D.M. Driscoll. 2000. Molecular cloning of apobec-1 complementation factor, a nove RNA-binding protein involved in the editing of apolipoprotein B mRNA. Mol. Cell. Biol. 20:1846-1854

13.Sowden, M.P., N. Ballatori, K.L. de Mesy Jensen, L. Hamilton Reed, and H.C. Smith. 2002. The editosome for cytidine to uridine mRNA editing has a native complexity of 27S: identification of intracellular domains containing active and inactive editing factors. J. Cell. Sci. 115:1027-1039

We thank Jenny M.L. Smith for the preparation of the figures. This work was supported by Public Health Services grant no. DK43739 (awarded to H.C.S.), a De- partment of Defense, an Air Force grant (awarded to H.C.S. and M.P.S.), a University of Rochester Medical Center Pilot Project, and a Xerox REACH fellowship (awarded to M.P.S. and C.A.G. respectively). Address correspondence to Dr. Harold C. Smith, Department of Biochemistry and Biophysics, University of Rochester, 610 Elmwood Ave., Rochester, NY 14642, USA. e-mail: harold_smith@urmc.rochester.edu

Received 5 December 2002; accepted 21 January 2003.

\section{Chad A. Galloway, Mark P. Sowden, and Harold C. Smith University of Rochester Rochester, NY, USA}

\section{Generation of Chromo- some Paints: Approach for Increasing Specificity and Intensity of Signals}

BioTechniques 34:530-536 (March 2003)

\section{ABSTRACT}

Chromosome painting is a widely used technique, and the two principal means of generating probes for such experiments involve DNA isolation by chromosome flow sorting and by chromosome microdissection. Frequently, chromosome paints are bright and specific; however, on occasion, signals can be weak and nonspecific, particularly for microdissected probes. Reasons for this have been attributed to co-amplification of non-target DNA and the formation of primer concatamers during degenerate oligonucleotide primed (DOP)PCR. Here we describe a technique of circumventing this problem by sequence enrichment. It involves co-hybridization of DOP-PCR biotinylated microdissected material and linkered genomic DNA. Biotinylated DNA fragments captured on strepta- vidin-coated paramagnetic beads are eluted and amplified by PCR using a single primer complementary to the linker arm.

\section{INTRODUCTION}

Chromosome painting has a wide range of applications including clinical cytogenetics, genome organization studies, hybrid characterization, and comparative genomics. Chromosome microdissection and flow cytometry are both well-established means of generating chromosome painting probes $(1,2)$. Following isolation by either of these approaches, chromatin can be amplified and labeled by degenerate oligonucleotide primed (DOP)-PCR to produce a paint $(1,3)$. Flow cytometry is the preferred approach for isolating whole chromosome paints, while microdissection is the method of choice for generating sub-regional paints and whole-chromosome paints when individual chromosomes cannot be resolved in a flow karyotype; both have found specific utility in developing chromosome paints for nonhuman species $(2,4,5)$. With the near completion of the human genome project, paints can often be generated by selecting a library of clones from the region of interest (6); however, such a strategy is less practicable in nonhuman species, as fewer clones are available. In our own laboratory, we have found both flow cytometry and microdissection to be invaluable for generating chromosome-specific paints from chicken chromosomes (2).

Frequently, both approaches produce bright specific paints; however, on occasion, experiments result in nonspecific, weak signals. Reasons for this have been attributed to co-amplification of non-target DNA and the formation of primer concatamers during DOP-PCR amplification of the template DNA. This is likely to be more common in paints generated by microdissection, but, even for flow cytometry, if conditions are suboptimal (e.g., a slow-growing cell line from which the chromosomes are prepared or excess debris in the chromosome suspension), this can lead to chromosome paints that are not always as bright and specific as expected. Indeed, these problems tend to be more evident when smaller templates are used (e.g., 